\title{
Churchill, Moran and the struggle for survival
}

\author{
AW Beasley \\ Retired Orthopaedic Surgeon, Wellington, New Zealand
}

\begin{abstract}
This paper examines the association between Winston Churchill and Charles McMoran Wilson, later Lord Moran, who was made personal physician to Churchill in 1940 at the instigation of the Cabinet when Churchill became prime minister of wartime Britain.
\end{abstract}

KEYWORDS Churchill, Moran, medical history, Second World War
Correspondence to AW Beasley, 37 Hay Street, Oriental Bay, Wellington 6011 , New Zealand

tel. +6443845414 e-mail alwynbeasley@hotmail.com

DECLARATION OF INTERESTS No conflict of interests declared.

\section{INTRODUCTION}

On 10 May 1940 Winston Churchill became prime minister of a beleaguered Britain. He did so, moreover, by preserving his silence. An angry session of the Commons a few days earlier had persuaded Neville Chamberlain that he no longer commanded the respect of the House; a groundswell of public opinion favoured the choice of Churchill to succeed him. Not so the ruling Tory establishment, which had regarded Churchill as a turncoat and a warmonger for years and saw Lord Halifax - the foreign secretary, a giant of a man with a congenital defect in his left arm, skilled in debate and hence known variously as 'the Holy Fox' or 'Armless Eddie' - as Chamberlain's natural successor.

Finally on 9 May Chamberlain invited Halifax and Churchill to consult with him. 'Whatever you do,' Churchill's friend Brendan Bracken counselled him, 'don't say anything: let them do the talking.' Halifax demurred gently when Chamberlain sounded him out; as a peer he would, he suggested, be handicapped by his absence from the Commons. Churchill said nothing. Chamberlain finally turned to Churchill, who conceded that he was not so disadvantaged; and by default as it were, he became the successor of choice. ${ }^{2}$ Even then, Chamberlain might have tried to hang on, but the German assault on the Low Countries the next morning, and the news that the Labour Party had refused to join a war cabinet under him, left no further room to manoeuvre. During the afternoon he saw the king, and by evening Churchill had kissed hands.

The Cabinet Churchill assembled was composed in part of the men who had attempted for years to discredit him, but in part also of Labour stalwarts and his own protégés. One of these, Max Aitken, Lord Beaverbrook, he made minister in charge of aircraft production; at Beaverbrook's urging, the Cabinet secured for Churchill a personal physician. The choice fell on Professor Sir Charles McMoran Wilson (Figure I), who had been Dean of St Mary's Medical School for two decades, was a gifted administrator and had, in the previous couple of years, achieved some prominence in the Royal

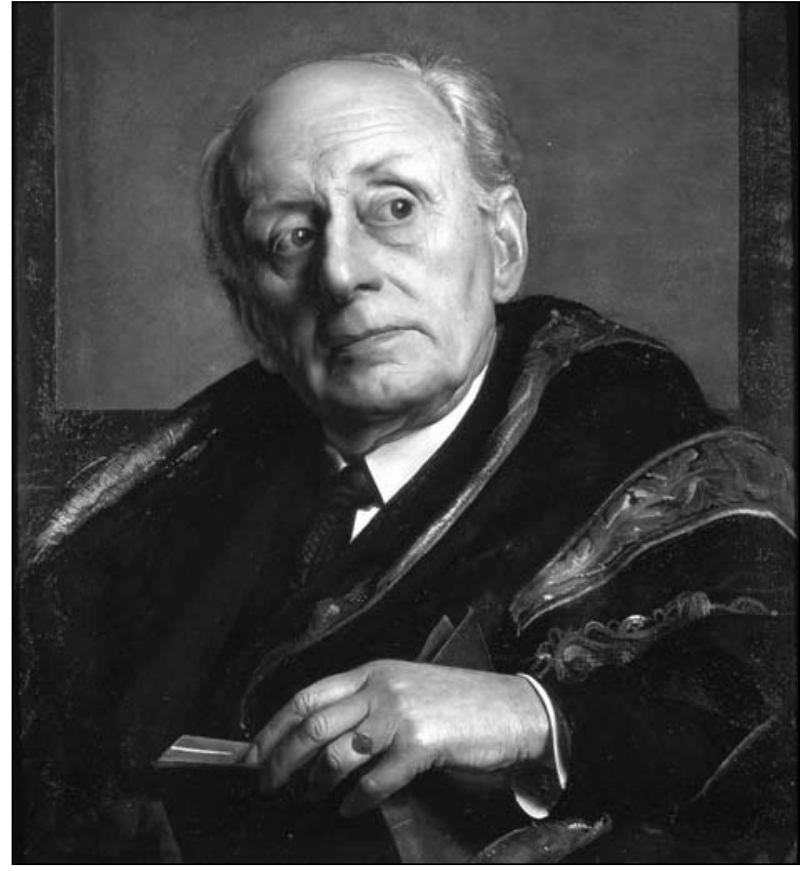

FIGURE I Charles McMoran Wilson, Ist Baron Moran of Manton, by Pietro Annigoni, 195I. (C) Royal College of Physicians of London.)

College of Physicians of London. Wilson wrote later, on 24 May 1940:

Winston Churchill is 65 . He has just been appointed Prime Minister, and I have become his doctor, not because he wanted one, but because certain members of his Cabinet, who realised how essential he has become, have decided that somebody ought to keep an eye on his health... I do not like the job, and I do not think the arrangement can last. ${ }^{3}$

However, it did last; indeed, it lasted for the remaining 25 years of Churchill's life. Their association ended only when Wilson, by then Lord Moran, delivered the news of Sir Winston's death to waiting newsmen outside the Churchill residence at 28 Hyde Park Gate. But then it all unravelled when Moran published what he described as his diaries from those years, one year after his patient's 
death and against the express wish of the Churchill family. It is appropriate to consider three things: the state of Churchill's health after 1940 (and, in passing, his medical adventures before his accession to the premiership), the care he received at Moran's hands and the private agenda that prompted Moran to publish as and when he did.

\section{CHURCHILL'S MEDICAL HISTORY}

As his doctor noted, Churchill was 65 when he became prime minister. He had been a frail child, subject to episodes of pneumonia, which was an alarming and often fatal disease in pre-antibiotic days. He had also developed a childhood hernia and had suffered a number of injuries when growing up - a fall from his bicycle which concussed him at the age of 13; a fall from a tree just before his entry into Sandhurst which left him unconscious for three days and confined to bed for a couple of months, with damage to one kidney and the suspicion of a fractured femur a couple of years before Röntgen's discovery of X-rays illuminated the diagnosis of bony injury; and a shoulder dislocation as he arrived in India with his regiment, which would become recurrent. ${ }^{4}$

Churchill had developed appendicitis in 1922, had been operated on late, as was common in those days, and found himself after that year's election 'without an office, without a seat, without a party and without an appendix'. ${ }^{5}$ $\mathrm{He}$ had been rendered momentarily tetraplegic when struck by a car in New York in 1931, and had suffered a profuse intestinal haemorrhage during an attack of paratyphoid the following year.

He was of mercurial temperament, and as a young man he had been depressed at intervals. He was also a keen sportsman who had won the Public Schools' fencing title in his time and had helped his regimental team win the polo championship in India in 1899, scoring three of his side's goals in a 4-3 victory with his arm strapped to his side because of a recent recurrence of his shoulder dislocation. Indeed, with this precaution he continued to play polo into his fifties.

During what have been called 'the wilderness years' in the 1930s, when it was fashionable to deride him as a warmonger because he railed against Britain's lethargy during the rise of Nazi Germany, Churchill's morale and general health had held up surprisingly well. At his appointment in 1940 he felt (as he wrote later) 'a profound sense of relief. At last I had authority to give directions over the whole scene. I felt as if I were walking with destiny, and that all my past life had been but a preparation for this hour and for this trial.'

But the combination of stresses that followed his appointment - the overrunning of the Low Countries, the evacuation at Dunkirk, the fall of France, the beginnings of

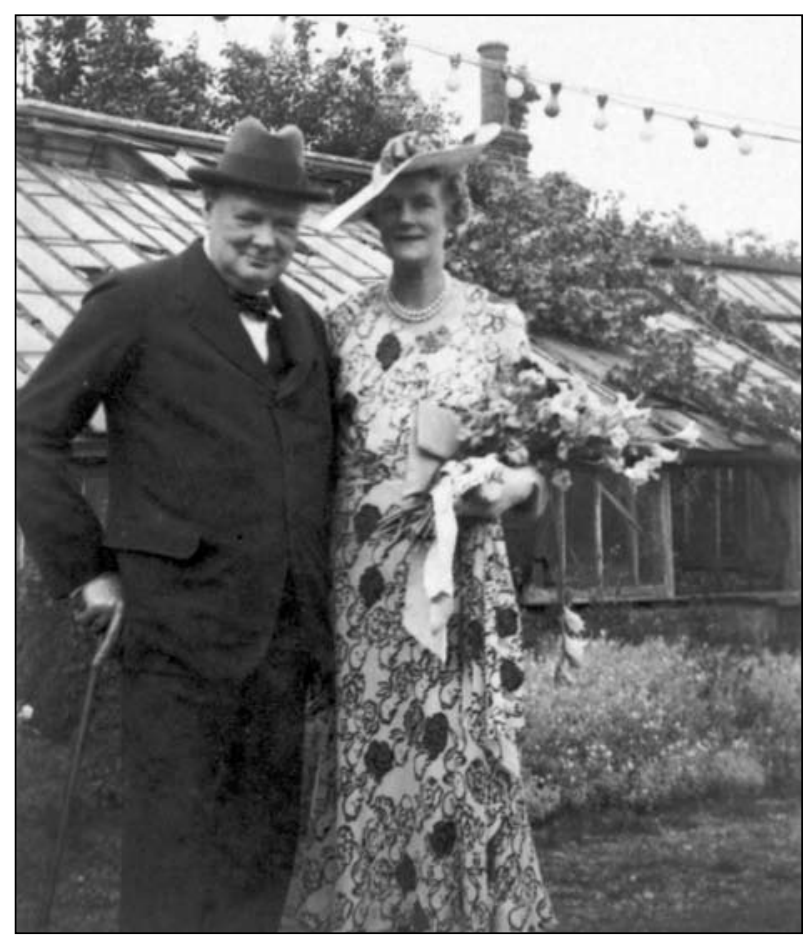

FIGURE 2 Winston and Clementine Churchill, photographed in the 1930s. (Baroness Spencer-Churchill Papers, Churchill Archives Centre. Reproduced courtesy of Churchill College, Cambridge.)

the Blitz and the very real threat of invasion - made him disagreeable, to the extent that his wife Clementine (Figure 2) wrote a private note to him:

My darling

A devoted friend has been to me \& told me that there is a danger of your being generally disliked... because of your rough sarcastic \& overbearing manner... I must confess that I have noticed... you are not so kind as you used to be. ${ }^{7}$

Having written thus, she tore up the letter but a few days later pieced it together and gave it to her husband. For whatever reason (and Clementine was the perfect wife, loyal but never cowed) things improved to the extent that Anthony Eden could write, that November: 'It is really wonderful that at the end of [the last six months] you are fitter \& more vigorous, and better able than ever to guide $\&$ inspire us all. ${ }^{8}$

'Guide and inspire' - it is easy to overlook the fact that, after Dunkirk, Britain had little to speak of except Churchill's oratory and the young men of the Royal Air Force as resources against an early defeat. By 194I Churchill had determined that the only hope of victory (as distinct from avoiding defeat) lay in actively promoting co-operation with the US; he travelled to Placentia Bay in Newfoundland in August, six weeks after Hitler's invasion of Russia, to meet the American president Franklin D Roosevelt and thrash out an agreement that the US would support the combatants with massive aid 
while, paradoxically, remaining neutral itself. Four months later, Japan's attack at Pearl Harbor resolved that paradox and the US found itself at war.

Within three weeks Churchill met Roosevelt again, this time in Washington, where he addressed a joint session of Congress:

I cannot help reflecting that if my father had been American and my mother British, instead of the other way round, I might have got here on my own. In that case, this would not have been the first time you would have heard my voice. ${ }^{9}$

They loved it.

\section{CARING FOR A PRIME MINISTER}

That night, however, staying at the White House, Churchill found the room so hot that he decided to open the bedroom window. As he described to Wilson the next morning:

It was very stiff. I had to use considerable force and I noticed all at once that I was short of breath. I had a dull pain over my heart. It went down my left arm. ${ }^{10}$

This presented Wilson with a dilemma which he confided to his diary:

His symptoms were those of coronary insufficiency. The textbook treatment for this is six weeks in bed. That would mean publishing to the world - and the American newspapers would see to this - that the PM was an invalid with a crippled heart and a doubtful future. And this at a moment when America has just come into the war, and there is no one but Winston to take her by the hand. I felt that the effect of announcing that the PM had had a heart attack could only be disastrous. I knew, too, the consequences to one of his imaginative temperament of the feeling that his heart was affected. His work would suffer On the other hand, if I did nothing and he had another and severer attack - perhaps a fatal seizure - the world would undoubtedly feel that I had killed him through not insisting on rest. These thoughts were racing through my head while I was listening to his heart. ${ }^{10}$

Taking his courage in both hands, he advised Churchill:

It is nothing serious. You needn't rest in the sense of lying up, but you mustn't do more than you can help in the way of exertion for a little while. ${ }^{10}$

It was therapy years ahead of its time. But Wilson worried, rightly enough, because in the medical climate of the 1940s his management of the White House episode bordered on the cavalier. From the diaries of General Sir Alan Brooke (later Lord Alanbrooke), the Chief of the Imperial General Staff, it is evident that his worrying was deep and durable;" and Wilson himself wrote about his risk of emulating Sir Morell Mackenzie, who failed to diagnose the throat cancer of the German Crown Prince in 1887 and was crucified for his error.

However, Wilson's proper concern did not translate into proper precaution. In North Africa, after his Tehran meeting with Stalin in November 1943, Churchill developed pneumonia while staying at Carthage. He sent for Wilson (by now ennobled as Lord Moran), but when he went into atrial fibrillation Moran had to 'send to Tunis for digitalis. ${ }^{12} \mathrm{~A}$ prudent doctor, responsible for the health of a man with a coronary history, would have turned up with a supply of digitalis - for there were only a few effective heart drugs in those days, and the foxglove yielded one of them. 'It was four hours before the heart resumed its normal rhythm,' Moran recorded. ${ }^{2}$ Then the pneumonia itself had to be treated, in this instance with sulphonamides (known as 'M\&B' after their makers' name), which were in the 'wonder drug' category at that time.

Harold Macmillan, who was minister resident at Allied Headquarters in north-west Africa at the time, recorded in his own diary:

At last a Colonel Buttle - the great M\&B specialist - arrived from Italy. He is an expert on how to give the stuff. He seems clever, determined, rather gauche and rude - just the chap we need. I had a long talk with him and begged him to be firm and forbid telegrams or visitors. ${ }^{13}$

Moran, who makes no reference to Buttle's role in these activities, observed that 'Harold Macmillan is inclined to fuss... Any decisions that have to be made are going to be made by me and no one else.' ${ }^{\prime 2}$

The second criticism of Moran's recorded management of his eminent patient concerns the extent to which he supplied Churchill with barbiturates, known in their private jargon as 'reds'. ${ }^{14}$ Certainly the effect of regular barbiturate dosage was less well appreciated in the 1940s than it later became, but these 'reds' are mentioned often enough in Moran's diary that it may be wondered how Churchill managed to function as well as he did.

The next concern dates from an earlier episode of pneumonia, back in England in February 1943. When chest X-rays showed a small shadow, Moran consulted Dr Geoffrey Marshall of Guy's Hospital in London.

It was not until the 24th [a week after the X-ray] that the temperature fell, but we were at no time 


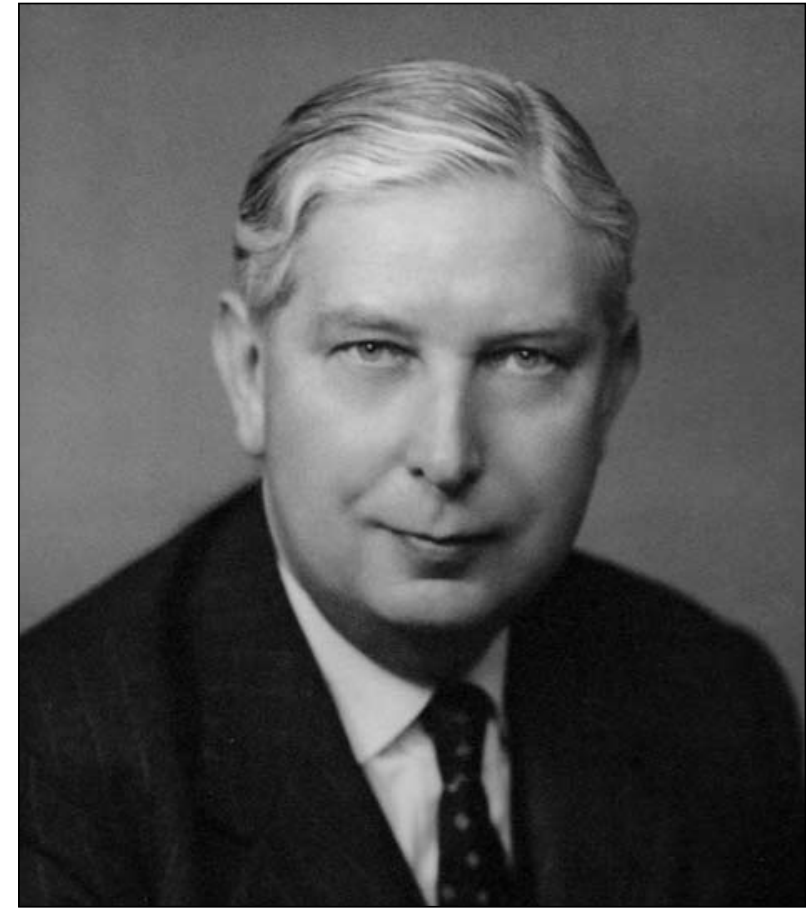

FIGURE 3 Russell, Lord Brain, who saw Churchill in consultation. (With kind permission of Dr Michael C Brain.)

concerned about his condition. When a man approaching his seventieth year gets pneumonia it is, broadly speaking, the heart and not the lungs that decides the issue. Winston's heart, which nine months later was to cause us anxiety at Carthage, did not worry us then. The patient himself took a more serious view of his illness. Apart from his appendix, he had never been seriously ill [author's italics]. ${ }^{15}$

The brief summary of Churchill's medical history above is itself enough to refute the italicised statement, and it becomes necessary to account for it. Either Moran (a former medical school dean) had been remiss in his history-taking to an extent that would have disgraced one of his students or, as seems more likely, he was writing in pursuit of a private agenda.

\section{A CONTROVERSIAL FIGURE}

In the year after Churchill's death, Moran published what purported to be his diary from the Churchill years. He chose the subtitle 'the struggle for survival' and set out, it seems, to describe how he, the loyal physician, had kept a wreck of a prime minister alive. Sir Martin Gilbert, the official Churchill biographer, has described how, after the accession of Moran's papers to a 'leading medical library in London', he

asked for the diary entry for a single date (I wanted to reproduce the published version in facsimile in the second of my... document volumes). To my dismay, not merely for myself but for historical truth, I was told by the custodian of the papers that there was no entry for that day at all, even though an entry under that exact date appears in the published book. Even the entries that did exist, I was told, were "not a diary in the accepted sense of the word'.16

That is to say, Moran's diary is a spurious document. Indeed, the phrase "not a diary in the accepted sense of the word' is used repeatedly in the catalogue of the Moran papers in the Wellcome Library - as if to deflect criticism of such a literary device. This catalogue points to its use in the prefaces to Moran's published work, which glosses over the fact that, in Churchill - the Struggle for Survival, the term is applied to the author's First War recollections.

Moran's publication, of course, raised a storm of controversy. The Lancet deplored his breaking patient confidentiality in the way he did, as 'creating a bad precedent which none should follow'. ${ }^{17}$ Setting aside the tautology, that is stern criticism. There was a vigorous debate in the correspondence columns of The Times, with Randolph Churchill (Winston's son and, until his death, official biographer) and several loyalists from Churchill's staff taking issue with the precipitate publication, as well as the content, of the book and Moran seeking to justify himself and being contradicted by both interested and disinterested parties.

Lord Brain (Figure 3), the former Russell Brain, the neurologist who had seen Churchill in consultation several times and, as it happens, succeeded Moran as president of the Royal College of Physicians of London, took issue with passages in which his opinion had been misrepresented, while at the same time he paid gracious tribute to Moran's devotion and was prepared to overlook passages that disparaged his own abilities.

One distortion of Brain's advice stands out: he saw Churchill, who was quite sure that the tightness over his shoulders [had] increased:

The cells in your brain, [Brain] explained, 'which receive sensory messages from your shoulder are dead. That's all. It's a bit of luck that sensation only is affected.' ${ }^{\prime 8}$

It is difficult to imagine that dead sensory cells would transmit sensation of tightness or anything else. It is equally difficult to believe that Brain phrased his advice in these terms. Nor is Moran's description of Brain ('he has a first-rate intelligence, but it is hidden behind a rather ordinary exterior' ${ }^{\prime 9}$ ) exactly felicitous.

Moran's self-serving account has generated its share of Churchill myths, not least the one that Churchill suffered from depression as a disease because he spoke of the 'black dog' that afflicted him at times. Aware that 


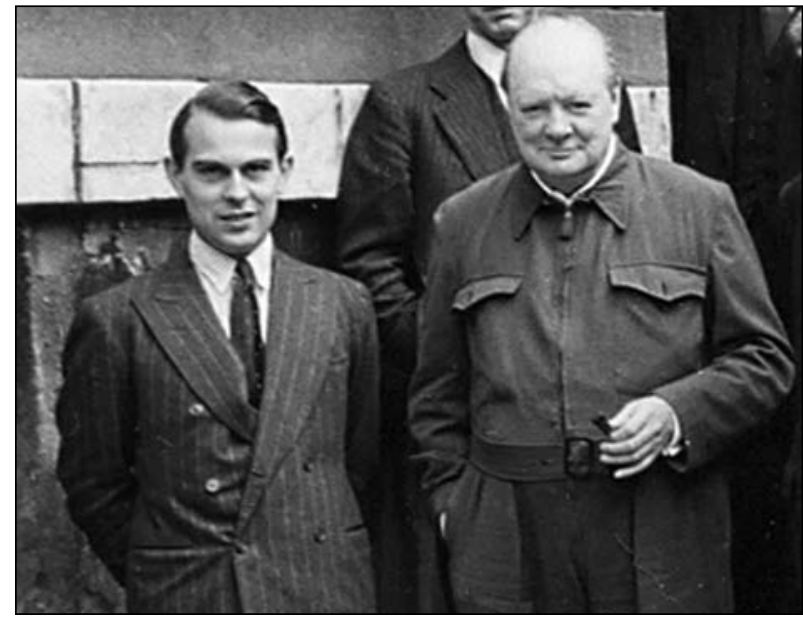

FIGURE 4 Churchill with Sir John Colville. (Reproduced from the estate of the late Sir John Colville with kind permission from Mrs David Bowes-Lyon.)

Churchill's fierce resolution as wartime leader did not fit well with this diagnosis, Gilbert set out to investigate. He received a letter on the subject from Jock (Sir John) Colville (Figure 4), who was Churchill's long-serving secretary and close friend:

I suppose that this hypothetical state of depression into which Lord Moran alleges Sir Winston used to fall will become accepted dogma. I therefore, some time ago, took the trouble to ask Lady Churchill about the theory. She was quite positive that although her husband was occasionally depressed as indeed most normal people are - he was not abnormally subject to long fits of depression.

The expression 'to have a black dog on one's back' was one that my nanny used to use very frequently. I suspect that Mrs Everest [Churchill's nanny and surrogate mother] must have used it too. It was a very common expression among nannies. I think that Sir Winston must have said on various occasions to Lord Moran: 'I have got a black dog on my back today.' Lord Moran, not moving very frequently in nanny circles, evidently thought that this was some new and remarkable expression which Sir Winston applied to himself.

If I am right - and Lady Churchill thinks I am - this does show what dangerous errors historians can make, by being ignorant of the jargon of an age preceding their own. ${ }^{20}$

Misunderstanding is a well-established phenomenon among historians, and in the matter of depression it does seem to have overtaken Moran. But his so-called diary was not his first essay into the writing of books. In 1943 he put together a small book based on his observations of men in the trenches in the First World War. Discussing the birth pangs of that book he records
Churchill's failure to empathise with his assessment of courage and will-power as a soldier's capital assets. 'He has never given a thought to what was happening in a soldier's mind, he has not tried to share his fears.'2! This view does not fit Churchill's record as a battalion commander in that same war, when his concern for his men's welfare became almost legendary, but it fits Moran's patronising ruminations.

Moran was dejected when the publisher Macmillan turned him down, and planned to approach Constable next. Here he was successful, and in 1945 the book appeared as The Anatomy of Courage and became a respected treatise on courage in combat. It led to Moran's appointment to talk on the subject at the Staff College in Camberley. What Moran did not acknowledge was that he had written it as The Anatomy of Fear. Its three sections fit in with this theme: the discovery of fear, how courage is spent and the care and management of fear. The alteration in the title was made at Churchill's suggestion: with a positive word, Churchill told him, you will attract your readership.

In mid-1964, shortly before Sir Winston's death, Lady Churchill learned, through the press, that Moran was planning to write a book about his association with her husband. After talking with him she wrote:

I had always supposed that the relationship between a doctor and his patient was one of complete confidence... An impartial observer would... consider that your career had been a successful one and had not been damaged by your association with Winston, and I think he has shown himself not ungrateful to you. ${ }^{22}$

She received no reply to this letter, nor to a request to be shown the proofs. What she did receive, in January 1966, was a letter from Moran asking to use the 1916 Orpen portrait of her husband. She replied regretting that he had made the request, since he knew her to be unhappy about his plan.

This time she did get a reply: Moran pleaded that authors do not like to have their unfinished work examined, that he had been urged by the social historian GM Trevelyan, by Field Marshal Smuts and by Brendan Bracken to write the book and that he had sought to do justice to his subject. He repeated his request to use the Orpen - Clementine told him it now belonged to Randolph, and the matter was out of her hands. The portrait was not inserted.

The story was put about that Moran 'became an author because he needed the money'. It is difficult to see where this could have originated if not with Moran himself. It is a story which suppresses two important details - the first, that Churchill sought at the war's end 
to obtain a state pension for Moran, who rejected the proposal; and the second that Churchill had already in 1942 settled an annuity of $£ 500$ tax free for seven years on Lady Moran, and followed this in 1949 with a $£ 300$ annuity for each of Moran's two sons, payable from his own pocket. These gifts were renewed until Churchill's death; the boys at least were appreciative, whatever their father chose to plead. Lady Soames has commented on the 'charming and grateful letters' they wrote in 1956 when their covenants were renewed. ${ }^{22}$

It would be all too easy to dismiss Moran as a mere schemer whose self-promotion overtook his principles; but this is to do less than justice to a man of considerable distinction. In the trenches in 1916 he won a Military Cross and as a medical school dean he raised funding sufficient to establish outstanding facilities and built up a notable school. He was a long-serving president of the Royal College of Physicians of London and tucked away in that college is his presidential portrait, by Pietro Annigoni, which well captures the qualities of the man (Figure I). Indeed, the Royal College of Physicians of London's own guide to its possessions, in a discussion on the presidential portraits, comments on the flair with which the portrait captures Moran's cunning. It goes on to recount 'the story (unverifiable)' of Sir Winston's remark on seeing the Annigoni: 'Just right, Moran, [it] makes you look like a mediaeval poisoner. ${ }^{23}$ Unverifiable, perhaps, but highly credible. It is a pity that much of what Moran wrote about his celebrated patient is worse than unverifiable; it is, judged against other evidence, unreliable.

Looking back over the damage that Moran's venture into historical fiction has done, ${ }^{16}$ not least to his own reputation, one might wish that he had kept silent, as Churchill did on that fateful day in May 1940.

\section{REFERENCES}

I Brendon P. Winston Churchill: a brief life. London: Methuen; 1984. p. |4|.

2 Churchill WS. The Second World War. Vol I. London: Cassell; 1948. p. 523-4.

3 Moran C. Winston Churchill: the struggle for survival. London: Heron Books; 1966. p. 5.

4 Beasley AW. An approach to the natural: the Kenneth Russell memorial lecture. ANZ J Surg 2007; 77: 1045-52.

5 ChurchillWS. Thoughts and adventures. London: Odhams; 1947. p. 162.

6 Churchill WS. The Second World War. p. 526-7.

7 Gilbert M. Churchill: a life. London: Folio Society; 2004. p. 768.

8 Gilbert M. Churchill. p. 792.

9 Gilbert M. Churchill. p. 825.

10 Moran C. Winston Churchill. p. 16-7.

II Bryant A. The turn of the tide. London: Collins; 1957. p. 438, 493.

I2 Moran C. Winston Churchill. p. I5I.

I3 Macmillan H. War diaries: politics and war in the Mediterranean January 1943-May 1945. London: Macmillan; 1984. p. 327.

14 Moran C. Winston Churchill. p. II.

15 Moran C. Winston Churchill. p. 88.

16 Gilbert M. In search of Churchill: a historian's journey. London: HarperCollins; 1994. p. 233.

17 Anon. A question of confidence. Lancet 1966; 278:920. doi:10.1016/ SOI40-6736(66)9I594-7

18 Moran C. Winston Churchill. p. 337.

19 Moran C. Winston Churchill. p. 45I.

20 Gilbert M. In search of Churchill. p. 210.

21 Moran C. Winston Churchill. p. 127.

22 Soames M. Clementine Churchill: the biography of a marriage. London: Doubleday; 2002. p. 556-7.

23 Davenport G, McDonald I, Moss-Gibbons C, editors. The Royal College of Physicians and its collections. London: James \& James; $200 \mathrm{I}$. p. $|5|$.

\section{ADVANCED GASTROENTEROLOGY \& HEPATOLOGY COURSE}

\section{I0-II February 20I I}

This well-established two-day course is now in its 15 th meeting and attracts trainees and consultants from around the UK and Europe. It will highlight some of the new advances in the diagnosis and management of gastrointestinal and liver diseases. Overall, this will be an opportunity to update on the latest evidence base for the management and treatment of these conditions.

Day I places particular emphasis on the investigation and management of common problems in gastroenterology, including biological therapy and laparoscopic surgery in inflammatory bowel disease, coeliac disease, colon polyps and pancreatic cysts.

Day 2 covers, among other things, alcoholic liver disease, Baveno V, liver transplantation in the MELD era and non-invasive markers of liver disease.

\section{COURSE FEES:}

Full fee: $£ 350$

Fee if attending only I day: $£ 200$

For further details please see: http://events.rcpe.ac.uk or contact Anne Fairbairn at a.fairbairn@rcpe.ac.uk 